\title{
Sistem Administrasi Desa Mendiro Kecamatan Ngrambe Kabupaten Ngawi Berbasis Web
}

\author{
Annisa Dwi Rahmawati,Azizah Fatmawati \\ Program Studi Informatika \\ Universitas Muhammadiyah Surakarta (UMS) \\ Surakarta, Indonesia \\ 1200260093@student.ums.ac.id, af157@ums.ac.id
}

\begin{abstract}
Abstraksi- Administrasi merupakan suatu kegiatan pengelolaan, pengumpulan dan pelaporan data yang berupa pembukuan, ketik mengetik, pemaparan agenda dan suratmenyurat. Proses pembuatan surat menyurat yang masih manual merupakan salah satu permasalahan yang ada dalam instansi pemerintahan desa. Pembuatan surat dengan menggunakan aplikasi Microsoft Office memiliki beberapa kelemahan seperti tenaga perangkat desa yang tidak semua mempunyai kemampuan dalam pembuatan surat menyurat. Hal itu akan berakibat format surat berubah-ubah sesuai dengan kemampuan tenaga perangkat desa yang membuat, serta berdampak pada ketidakakuratan pencatatan data surat yang ada. Selain itu dibandingkan dengan tenaga administrasi yang lain, pada umumnya kemampuan IT tenaga perangkat desa masih dibawah rata-rata. Tujuan penelitian ini adalah untuk mengembangkan sistem administrasi desa di Desa Mendiro. Adapun metode yang digunakan adalah SDLC (System Development Life Cycle) dengan pendekatan waterfall. Tahapan dari metode tersebut meliputi perencanaan sistem, analisis sistem, perancangan sistem, implementasi sistem, dan pemeliharaan sistem. Pembangunan sistem administrasi desa ini menggunakan beberapa bahasa dan plugin, serta menggunakan framework codeigniter. Hasil dari penelitian ini berupa sistem administrasi desa berbasis web. Berdasarkan hasil pengujian Black Box yang telah dilakukan, sistem dapat berjalan sesuai dengan fungsi dan fitur yang telah dirancang sejak awal penelitian. Sistem dapat melakukan pencatatan data penduduk dan melayani pembuatan surat menyurat. Sedangkan hasil pengujian dengan SUS diperoleh nilai rata-rata 73.5 yang menunjukan bahwa sistem termasuk dalam kategori Usable.
\end{abstract}

Katakunci-administrasi, desa, surat menyurat, web

\section{PENDAhUluan}

Administrasi secara umum berfungsi sebagai pengelolaan, pengumpulan, dan pelaporan data, secara khususnya administrasi memiliki fungsi dalam ketik mengetik, pembukuan, pemaparan agenda dan surat-menyurat [1]. Pelayanan surat menyurat merupakan salah satu kegiatan yang penting disetiap desa. Terdapat beberapa jenis surat yang biasanya dilayani oleh desa seperti surat keterangan kelahiran, surat pernyataan, surat keterangan serbaguna, surat keterangan kematian, surat keterangan tidak mampu, surat keterangan berkelakuan baik, surat keterangan usaha, surat keterangan belum menikah dan beberapa surat-surat lainnya [2]. Pelayanan surat menyurat merupakan salah satu kegiatan yang penting disetiap desa. Terdapat beberapa jenis surat yang biasanya dilayani oleh desa seperti surat keterangan kelahiran, surat pernyataan, surat keterangan serbaguna, surat keterangan kematian, surat keterangan tidak mampu, surat keterangan berkelakuan baik, surat keterangan usaha, surat keterangan belum menikah dan beberapa surat-surat lainnya

Pembuatan surat oleh perangkat desa di Kantor Desa Mendiro menggunakan aplikasi Microsoft office. Tidak semua tenaga perangkat desa mempunyai kemampuan komputer dalam pembuatan surat menyurat yang seragam, dimana hal tersebut membuat pelayanan administratif desa sangat tergantung terhadap tenaga administratif tertentu. Perbedaan kemampuan sumber daya manusia dalam proses pembuatan surat memungkinan terjadinya perbedaan format surat yang berubah-ubah serta rawan terhadap keakuratan pencatatan data surat yang telah dibuat [3].

Sistem informasi administrasi beberapa tahun terakhir sering digunakan dalam perusahaan bisnis, hal ini dapat dijadikan contoh kedalam ruang lingkup pemerintahan, karena seiring dengan perkembangan tekonogi dan komunikasi akan menjadi solusi dari masalah yang ada [4]. Aplikasi pelayanan administrasi berbasis web juga digunakan untuk membantu mengatasi kelemahan sistem manual, terutama dalam melakukan pembuatan surat menyurat secara komputerisasi [5]. Adanya sistem yang terkomputerisasi juga mempermudah dan mempercepat dalam pencarian data yang ada [6], serta sistem dapat digunakan untuk pembuatan laporan pengelolaan surat yaitu perekapan surat [7]. Kebutuhan administrasi yang baik dan benar didalam setiap organisasi bertujuan untuk memaksimalkan hasil kerja dan mempercepat penyampaian informasi di dalam organisasi tersebut.

Berdasarkan permasalahan yang dialami di Kantor Desa Mendiro, sistem administrasi desa yang terkomputerisasi akan memudahkan pembuatan surat menyurat di desa tersebut, yakni menjadi lebih cepat dan akurat sesuai data yang dimiliki 
setiap penduduk Desa Mendiro. Pembuatan sistem administrasi desa diyakini dapat menutupi kendala-kendala yang terjadi dalam sistem pelayanan administrasi secara manual yang saat ini digunakan [8].

Sistem informasi administrasi canvasser pada PT. Metta Surya Sampit dibangun dengan berbasis desktop. Sistem tersebut bertujuan untuk mengatasi masalah dari segi pencatatan keuangan, inventori, dan laporan-laporan administrasi lainnya yang berada di perusahaan bidang pendistribusian produk dan pulsa elektrik. Sistem ini dibuat dengan Microsoft Visual Studio 2013 [1]. Sistem informasi administrasi pengelolaan surat di organisasi yang telah dibangun berupa pengelolaan surat yang bersifat pengarsipan dan pelaporan [9]. Tujuan dari sistem tersebut adalah memperbaiki sistem konservatif dalam organisasi, yakni pengarsipan surat yang masih disimpan dalam buku besar dan ditumpuk berupa hardcopy. Adanya pembangunan sistem informasi administrasi dirasa bermanfaat khususnya pada pengelolaan surat menyurat di organisasi tersebut.

Sistem administrasi dibidang organisasi. Administrasi dibidang organisasi tersebut meliputi pengarsipan surat, pengelolaan inventori, dan kalatog buku [10]. Sistem tersebut dirasa dapat menunjang pengelolaan administrasi yang baik dan berkualitas. Sedangkan sistem administrasi kependudukan yang dibangun berupa sistem permintaan surat yang dilakukan secara online. Sistem tersebut berfokus kepada penduduk untuk melakukan permintaan pembuatan surat [11].

Perbedaan antara penelitian terdahulu dengan penelitian sekarang terletak pada pengelolaan sistem. Pengelolaan sistem terdahulu terfokus kepada pengarsipan surat, permintaan surat, dan inventori. Sedangkan sistem administrasi desa terdapat pengembangan berupa pembuatan surat keluar secara otomatis yang ketika tenaga perangkat desa telah mengisi formulir surat keluar maka surat akan secara otomatis tercetak dalam bentuk draf yang sesuai dengan format surat. Draf surat yang tercetak berekstensi .pdf dan memiliki QR-Code di setiap suratnya bertujuan untuk meminimalisir adanya pemalsuan yang dilakukan oleh pihak yang tidak bertanggung jawab [12].

Adanya pengembangan sistem informasi ini diharapkan dapat mempermudah perangkat desa dalam melayani penduduk. Secara khusus dapat mengatasi kelemahankelemahan administrasi secara manual, terutama dalam proses pembuatan surat menyurat. Perekapan surat yang terkomputerisasi juga akan mempermudah pembuatan laporan pengelolaan surat dan mempercepat pencarian data yang ada [13].

\section{MEtode}

Penelitian pada sistem informasi ini menggunakan metode SDLC (System Development Life Cycle) dengan model pendekatan Waterfall. SDCL terdiri dari beberapa fase yang dimulai dari fase perencanaan, analisis, perancangan, implementasi hingga pemeliharaan sistem [14]. Konsep SDLC mendasari berbagai model pengembangan perangkat lunak untuk membentuk suatu kerangka kerja perencanaan dan pengendalian pembuatan sistem informasi. Tahapan model pengembangan waterfall ini ditunjukan pada Gambar 1 [15].

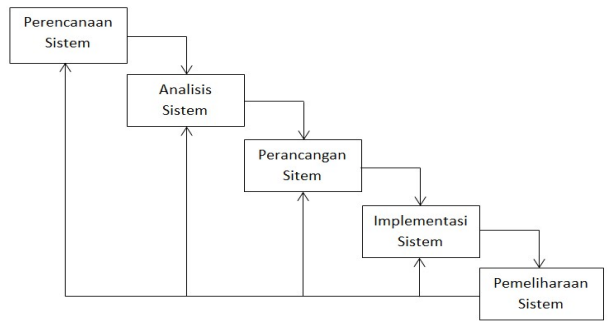

Gambar 1. Model Pengembangan Waterfall

\section{A. Perencanaan Sistem}

Tahapan penlitian ini bertujuan untuk pengumpulan data terkait kondisi dan kebutuhan perancangan sistem administrasi desa di desa Mendiro agar berjalan sesuai dengan prosedur yang ada di kantor kepala desa Mendiro. Diharapkan sistem ini dapat sesuai dengan kebutuhan dari kantor kepala desa Mendiro. Metode pengumpulan datanya menggunakan metode wawancara, observasi, dan studi pustaka [16].

1) Metode Wawancara atau Interview

Metode wawancara atau Interview adalah pengumpulan data atau informasi dengan cara mencari informasi secara langsung dengan pihak terkait, yaitu Sekretaris desa Mendiro sebagai narasumber.

2) Metode Observasi

Metode observasi adalah sebuah metode pengumpulan data dengan cara mengamati langsung objek yang akan diteliti serta mencari tahu informasi yang sudah ada sebelumnya.

3) Metode Pustaka

Metode pustaka adalah sebuah metode pengumpulan data dengan mencari referensi atau teori yang diperlukan, baik melalui buku, internet maupun data-data tertulis atau dokumen dari pihak yang bersangkutan.

\section{B. Analisis Kebutuhan Sistem}

Pengumpulan data yang dilakukan oleh peneliti di kantor desa Mendiro menunjukan bahwa sistem administrasi yang ada di desa tersebut kurang efektif dan efisien. Oleh karena itu, diperlukan pengembangan sistem untuk menyelesaikan permasalahan, yaitu dengan sistem administrasi desa Mendiro, kecamatan Ngrambe, kabupaten Ngawi berbasis $W e b$.

Kebutuhan fungsional sistem administrasi desa untuk surat keluar berupa nomor surat, tanggal kirim surat, alamat penerima surat, isi surat, kategori surat dan keterangan. Semua data akan disimpan didalam database untuk dijadikan informasi. Pengelolaan surat diperlukan administrator, yaitu seseorang yang bertugas memonitoring dan mengelola seluruh data dengan kontrol penuh, melakukan perbaikan jika ada kesalahan pemasukan data serta penghapusan data yang salah.

Kebutuhan non fungsional dalam pengembangan sistem ini antara lain, kebutuhan perangkat keras yaitu seperangkat komputer untuk memasukan informasi baru dari kantor desa 
Mendiro, sedangkan perangkat lunak yang dibutuhkan berupa operating system menggunakan Windows $(\mathrm{XP}, 7,8,10)$ yang mendukung aplikasi XAMPP dan Web. Aplikasi XAMPP digunakan sebagai tulang punggung server website. Dibutuhkan juga Sublime text sebagai text editor dan Web Browser untuk menjalankan sistem..

\section{Perancangan Sistem}

Pengembangan sistem ini menggunakan UML (Unifield Modelling Language) yaitu use case diagram. Use case dapat digunakan untuk mengumpulkan persyaratan dalam mengembangkan sistem [17]. Langkah pertama dalam penggunaan sistem yaitu admin login terlebih dahulu. Admin sebagai aktor dapat melakukan kegiatan yang berhubungan dengan pengelolaan seluruh kegiatan yang berkaitan dengan pembuatan surat. Pengelolaan data berupa input, edit, delete, dan view data [18]. Rincian dari usecase diagram admin terdapat pada Gambar 2.

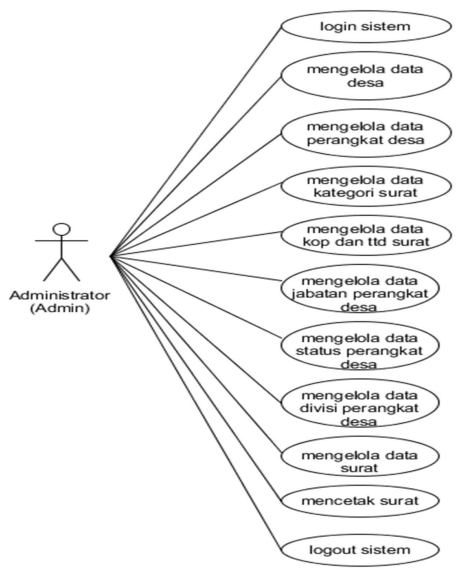

Gambar 2. Use Case Diagram Admin

Database didalam sistem ini terdiri dari 9 tabel yaitu tabel admin, tabel perangkat_desa, tabel desa, tabel jabatan, tabel divisi, tabel status, tabel warga, tabel surat, dan tabel kategori_surat seperti yang ditunjukan oleh Gambar 3.

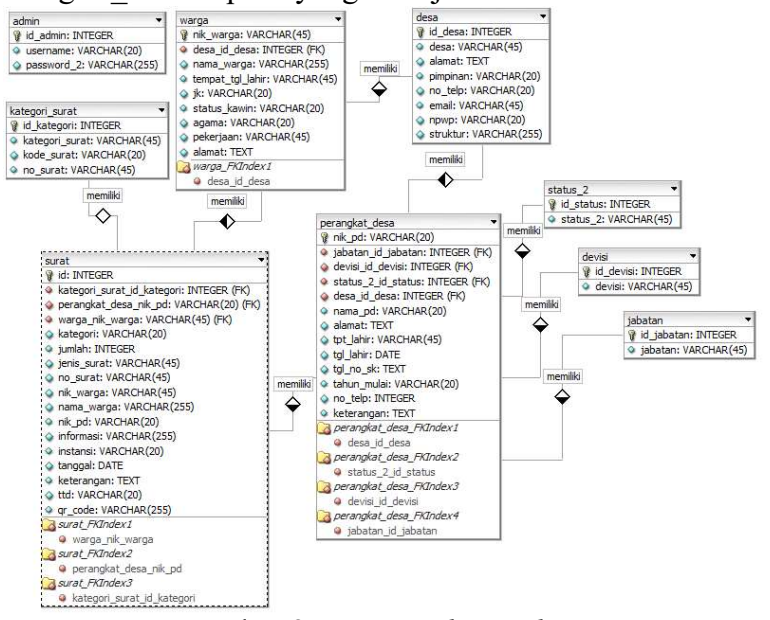

Gambar 3. Entity Relationship Diagram
Administrator dapat melakukan proses pembuatan surat dengan cara memasukan data identitas surat kedalam formulir. Ketika surat telah disimpan maka administrator dapat mengelola surat dengan mengubah, mencetak, dan menghapus surat. Kegiatan tersebut ditunjukan pada Gambar 4.

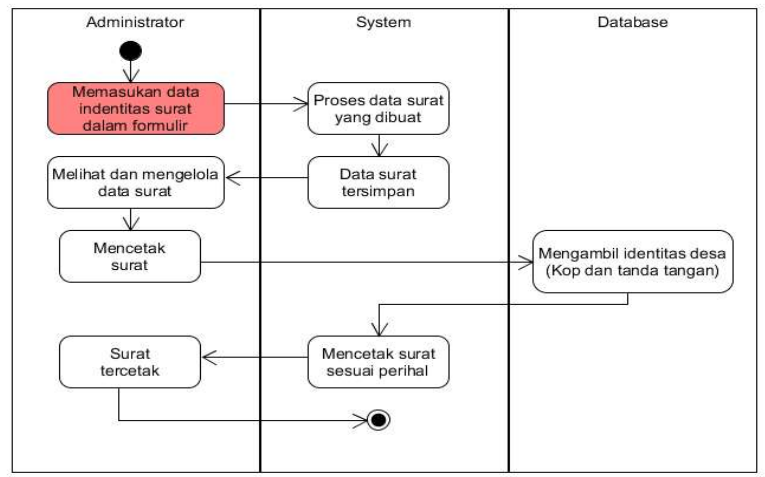

Gambar 4. Activity Diagram Pembuatan Surat

D. Implementasi Sistem

Sistem Administrasi Desa Mendiro, Kecamatan Ngrambe, Kabupaten Ngawi Berbasis Web ini dibuat menggunakan beberapa bahasa dan plugin yakni MySQL, PHP, Bootstrap, Code Igniter, dan Sublime Text Editor. Dengan menggunakan bantuan program tersebut diharapkan sistem ini dapat digunakan secara mudah dan praktis oleh pengguna. Pencetakan surat berekstensi .pdf diharapkan mempermudah pengguna dalam mengunduh dan mencetak surat melalui printer. Implementasi $Q R$-Code dengan merubahnya kedalam file image/ .png dan ditempatkan kedalam surat berguna sebagai legalitas dan keaslian surat yang dibuat [19].

Pengujian menggunakan black box untuk sistem yang berbasis website berfokus pada proses memasukan data (input) dan hasilnya (output) [20]. Pengujian dilakukan apakah semua hasil input, update, delete data surat dan semua data yang berkaitan dengan surat dapat ditampilkan pada website, hal ini dilakukan untuk memastikan jika masih terdapat bug didalam website. Selain itu dilakukan pengujian dengan metode System Usability Testing (SUS). Pengujian ini dilakukan dengan kuisioner untuk mengevaluasi sistem yang telah dibuat dari sudut pandang pengguna [21]. Pengujian bertujuan sebagai penilaian apakah sistem yang dikembangkan dapat dinyatakan berhasil atau gagal dan untuk memperlihatkan keakuratan fitur utama di dalam sistem [22].

\section{E. Pemeliharaan Sistem}

Pemeliharaan sistem atau maintenance akan dikelola sepenuhnya oleh penanggungjawab dari pihak Pemerintahan Kepala Desa Mendiro. Pemeliharaan sistem dilakukan apabila terdapat kesalahan dalam pengelolaan administrasi. 


\section{HASIL DAN PEMBAHASAN}

\section{A. Hasil}

Sistem administrasi desa Mendiro kecamatan Ngrambe kabupaten Ngawi berbasis Web telah dikembangkan sesuai dengan metode perancangan sistem. Hasil dari penelitian ini berupa sistem administrasi berbasis web yang mampu mempermudah tenaga perangkat desa dalam melayani pembuatan surat menyurat. Terdapat beberapa menu pada halaman awal sistem administrasi ini. Pada header terdapat beberapa menu profil untuk mengelola pengguna, menambah admin, dan logout untuk keluar. Pada sidebar terdapat beberapa menu untuk pengelolaan surat, daftar warga desa, daftar perangkat desa, laporan permintaan surat, dan setting sistem administrasi. Pada setiap halaman, pengelolaan data memiliki fungsi memasukan dan menyimpan data kedalam database, mengubah data, mencetak dengan ekstensi pdf, dan menghapus data. Filter pada halaman laporan berfungsi untuk mencari data sesuai rentang tanggal yang diinginkan, dan dapat dicetak dalam bentuk pdf. Setiap surat yang dicetak terdapat $Q R$-Code yang berungsi sebagai legalitas atau keaslian surat.

1) Halaman Utama Halaman utama pada Gambar 5 menampilkan dashboard setelah admin melalukan login sistem.

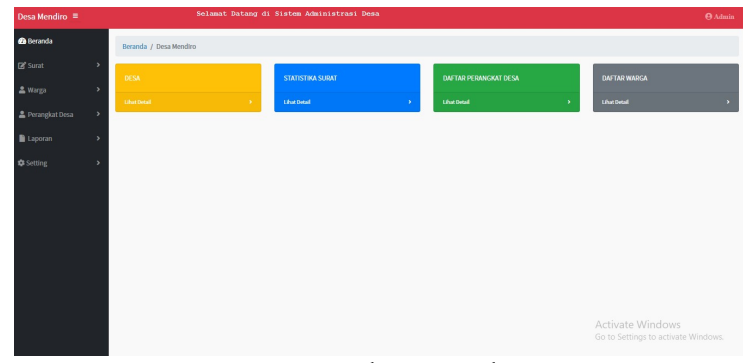

Gambar 5. Halaman Utama

2) Halaman Daftar Surat Keluar

Halaman daftar surat keluar menampilkan tabel data surat keluar dengan memiliki fungsi mengubah, mencetak, dan menghapus surat yang ditunjukan oleh Gambar 6 . Mengubah data surat keluar berisi data dalam bentuk form input yang perlu dicatat untuk pendataan surat. Apabila isi data disimpan akan ditambah ke basis data.

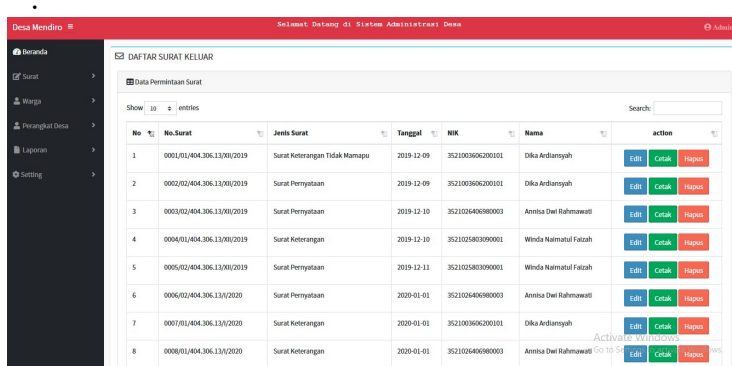

Gambar 6. Halaman Daftar Surat Keluar

\section{3) Halaman Surat Eksternal}

Gambar 7 menampilkan halaman pembuatan surat eksternal. Surat eksternal merupakan surat yang diminta oleh warga desa, yaitu surat keterangan dan surat pernyataan. Diantaranya terdapat kolom data warga yang diambil dari tabel warga, kolom nomor surat, isi singkat surat, dan aksi.
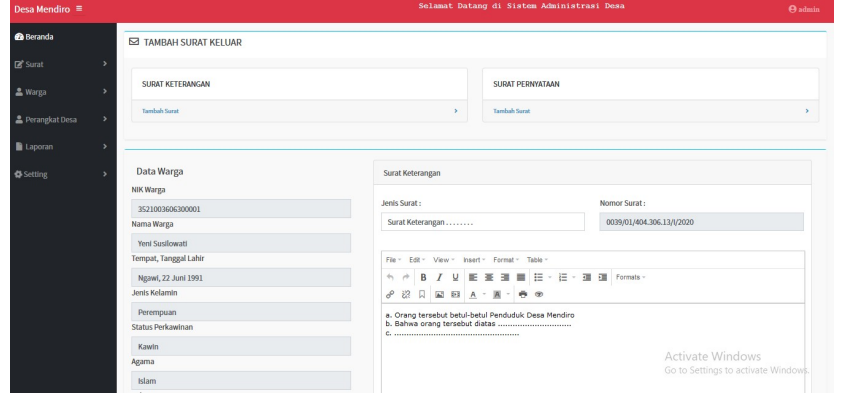

Gambar 7. Halaman Surat Eksternal

4) Halaman Surat dalam bentuk pdf

Gambar 8 menampilkan halaman surat yang telah dibuat.

Surat dapat dicetak atau diunduh dalam ekstensi pdf.

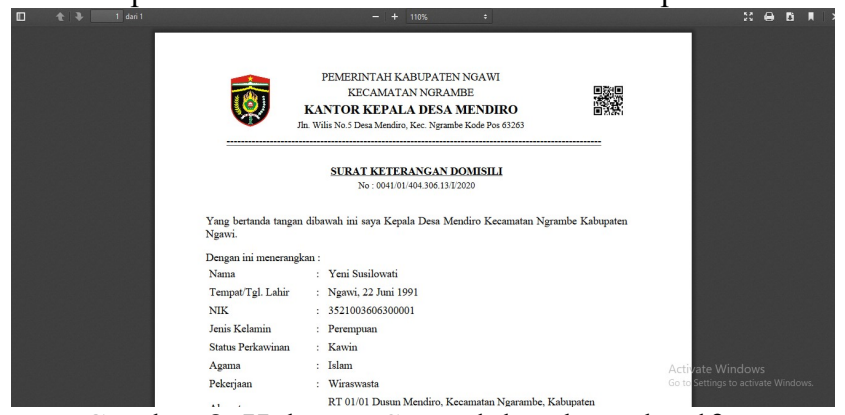

Gambar 8. Halaman Surat dalam bentuk pdf

5) Tampilan Laporan

Gambar 9 menampilkan hasil laporan dalam rentang waktu tertentu. Laporan juga dapat dicetak dalam bentuk pdf yang berisi tanggal surat, nomor surat, jenis surat, nik warga/ nik perangkat desa, dan nama.

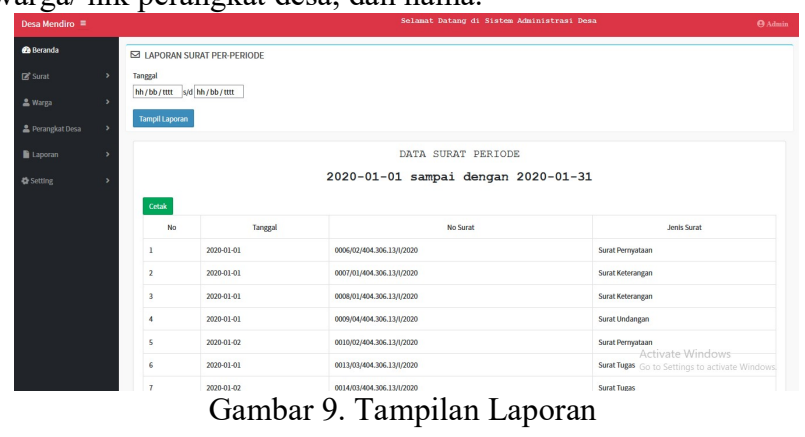

6) Statistiika Permintaan Surat

Halaman statistika surat berguna untuk menampilkan hasil laporan kategori surat tertinggi dalam bentuk grafik. Gambar 10 menunjukan grafik permintaan surat dengan garis horizontal menyatakan jenis kategori surat, 
sedangkan garis vertikal menyatakan jumlah surat yang keluar dalam setiap kategori. Batang grafik berwarna biru untuk menentukan total atau jumlah surat pada setiap kategori.

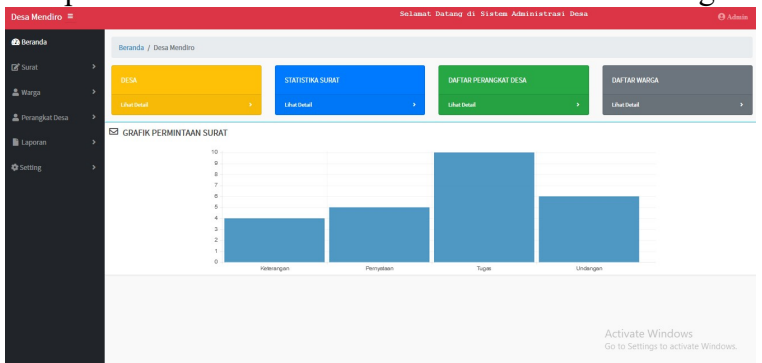

Gambar 10. Tampilan Laporan Grafik

\section{B. Pengujian dan Pembahasan}

1) Pengujian Black Box

Untuk memastikan sistem yang dikembangkan berjalan dengan baik atau tidak dilakukan pengujian black box. Tabel 1 menunjukan hasil pengujian black box yang menampilkan uji coba dengan kondisi tertentu dan harapan yang diinginkan. Apabila sesuai harapan dan tidak terjadi error hasil akan valid.

TABEL 1. PENGUJIAN BLACK BOX

\begin{tabular}{|c|c|c|c|c|}
\hline No & Pengujian & Test Case & Harapan & Hasil \\
\hline \multirow{2}{*}{1} & \multirow{2}{*}{ Login } & $\begin{array}{l}\text { Username Atau } \\
\text { Password Salah }\end{array}$ & $\begin{array}{l}\text { Tetap Dihalaman } \\
\text { Login }\end{array}$ & Sesuai \\
\hline & & $\begin{array}{l}\text { Username Atau } \\
\text { Password Benar }\end{array}$ & $\begin{array}{l}\text { Masuk Ke Halaman } \\
\text { Utama }\end{array}$ & Sesuai \\
\hline 2 & Logout & $\begin{array}{l}\text { Keluar Dari } \\
\text { Sistem }\end{array}$ & $\begin{array}{l}\text { Dapat Keluar Dari } \\
\text { Sistem Dan Kembali } \\
\text { Masuk Ke Halaman } \\
\text { Login }\end{array}$ & Sesuai \\
\hline 3 & $\begin{array}{l}\text { Setting } \\
\text { Admin }\end{array}$ & $\begin{array}{l}\text { Mengubah } \\
\text { Username Dan } \\
\text { Password }\end{array}$ & $\begin{array}{l}\text { Data Admin Dapat } \\
\text { Ditampilkan Dan } \\
\text { Diubah }\end{array}$ & Sesuai \\
\hline 4 & $\begin{array}{l}\text { Tambah } \\
\text { Admin }\end{array}$ & $\begin{array}{l}\text { Menambah } \\
\text { Username Dan } \\
\text { Password Admin } \\
\text { Baru }\end{array}$ & $\begin{array}{l}\text { Dapat Menambah } \\
\text { Admin Baru Kedalam } \\
\text { Database }\end{array}$ & Sesuai \\
\hline 5 & \multicolumn{4}{|l|}{ Beranda } \\
\hline & Desa & $\begin{array}{l}\text { Admin Menekan } \\
\text { Tombol Lihat } \\
\text { Detail Pada Desa }\end{array}$ & $\begin{array}{l}\text { Menampilkan Profil } \\
\text { Desa Berupa Struktur } \\
\text { Organisasi } \\
\text { Pemerintahan }\end{array}$ & Sesuai \\
\hline & $\begin{array}{l}\text { Statistika } \\
\text { Surat }\end{array}$ & $\begin{array}{l}\text { Admin Menekan } \\
\text { Tombol Lihat } \\
\text { Detail Pada } \\
\text { Statistika Surat }\end{array}$ & $\begin{array}{l}\text { Menampilkan } \\
\text { Statistika Surat Berupa } \\
\text { Grafik Sesuai Dengan } \\
\text { Kategori Surat }\end{array}$ & Sesuai \\
\hline & $\begin{array}{l}\text { Daftar } \\
\text { Perangkat } \\
\text { Desa }\end{array}$ & $\begin{array}{l}\text { Admin Menekan } \\
\text { Tombol Lihat } \\
\text { Detail Pada Daftar } \\
\text { Perangkat Desa }\end{array}$ & $\begin{array}{l}\text { Menampilkan Data } \\
\text { Perangkat Desa }\end{array}$ & Sesuai \\
\hline & & $\begin{array}{l}\text { Detail Perangkat } \\
\text { Desa }\end{array}$ & $\begin{array}{l}\text { Menampilkan Data } \\
\text { Perangkat Desa Sesuai } \\
\text { Dengan Id Yang } \\
\text { Dimaksud }\end{array}$ & Sesuai \\
\hline & $\begin{array}{l}\text { Daftar } \\
\text { Warga } \\
\text { Desa }\end{array}$ & $\begin{array}{l}\text { Admin Menekan } \\
\text { Tombol Lihat } \\
\text { Detail Pada Daftar } \\
\text { Warga Desa }\end{array}$ & $\begin{array}{l}\text { Menampilkan Data } \\
\text { Warga Desa }\end{array}$ & Sesuai \\
\hline
\end{tabular}

\begin{tabular}{|c|c|c|c|c|}
\hline No & Pengujian & Test Case & Harapan & Hasil \\
\hline & & Detail Warga & $\begin{array}{l}\text { Menampilkan Data } \\
\text { Warga Sesuai Dengan } \\
\text { Id Yang Dimaksud }\end{array}$ & Sesuai \\
\hline \multirow[t]{5}{*}{6} & \multicolumn{4}{|l|}{ Surat } \\
\hline & $\begin{array}{l}\text { Daftar } \\
\text { Surat } \\
\text { Keluar }\end{array}$ & $\begin{array}{l}\text { Admin Menekan } \\
\text { Daftar Surat } \\
\text { Keluar }\end{array}$ & $\begin{array}{l}\text { Menampilkan Data } \\
\text { Surat Keluar, } \\
\text { pengguna dapat } \\
\text { mengubah, mencetak } \\
\text { dan menghapus data }\end{array}$ & Sesuai \\
\hline & $\begin{array}{l}\text { Surat } \\
\text { External }\end{array}$ & $\begin{array}{l}\text { Admin Menekan } \\
\text { Surat External }\end{array}$ & $\begin{array}{l}\text { Menampilkan Daftar } \\
\text { Warga Yang Akan } \\
\text { Meminta Surat }\end{array}$ & Sesuai \\
\hline & & $\begin{array}{l}\text { Admin Menekan } \\
\text { Tombol Buat } \\
\text { Surat }\end{array}$ & $\begin{array}{l}\text { Menampilkan } \\
\text { Halaman Tambah } \\
\text { Surat Keluar Yang } \\
\text { Berisi Surat } \\
\text { Keterangan Dan Surat } \\
\text { Pernyataan, dan } \\
\text { membuat surat sesuai } \\
\text { format }\end{array}$ & Sesuai \\
\hline & $\begin{array}{l}\text { Surat } \\
\text { Internal }\end{array}$ & $\begin{array}{l}\text { Admin Menekan } \\
\text { Surat Internal }\end{array}$ & $\begin{array}{l}\text { Menampilkan } \\
\text { Halaman Tambah } \\
\text { Surat Tugas Dan Surat } \\
\text { Undangan, dan } \\
\text { membuat surat sesuai } \\
\text { format }\end{array}$ & Sesuai \\
\hline \multirow[t]{4}{*}{7} & \multicolumn{4}{|l|}{ Warga } \\
\hline & $\begin{array}{l}\text { Daftar } \\
\text { Warga } \\
\text { Desa }\end{array}$ & $\begin{array}{l}\text { Admin Menekan } \\
\text { Daftar Warga }\end{array}$ & $\begin{array}{l}\text { Menampilkan Daftar } \\
\text { Warga Desa, dapat } \\
\text { mengubah dan } \\
\text { menghapus data warga }\end{array}$ & Sesuai \\
\hline & & $\begin{array}{l}\text { Admin Menekan } \\
\text { Tambah Data } \\
\text { Pada Wargadesa }\end{array}$ & $\begin{array}{l}\text { Menampilkan Form } \\
\text { Input Identitas Warga } \\
\text { Desa }\end{array}$ & Sesuai \\
\hline & $\begin{array}{l}\text { Tambah } \\
\text { Warga }\end{array}$ & $\begin{array}{l}\text { Admin Menekan } \\
\text { Tambah Warga } \\
\text { Desa }\end{array}$ & $\begin{array}{l}\text { Menampilkan Form } \\
\text { Input Identitas Warga } \\
\text { Desa }\end{array}$ & Sesuai \\
\hline \multirow[t]{4}{*}{8} & $\begin{array}{l}\text { Perangkat } \\
\text { Desa }\end{array}$ & & & \\
\hline & $\begin{array}{l}\text { Daftar } \\
\text { Perangkat } \\
\text { Desa } \\
\end{array}$ & $\begin{array}{l}\text { Admin Menekan } \\
\text { Daftar Perangkat } \\
\text { Desa }\end{array}$ & $\begin{array}{l}\text { Menampilkan Daftar } \\
\text { Perangkat Desa }\end{array}$ & Sesuai \\
\hline & & $\begin{array}{l}\text { Admin Menekan } \\
\text { Tambah Data } \\
\text { Pada Perangkat } \\
\text { Desa }\end{array}$ & $\begin{array}{l}\text { Menampilkan Form } \\
\text { Input Identitas } \\
\text { Perangkat Desa, dapat } \\
\text { mengubah dan } \\
\text { menghapus data } \\
\text { perangkat desa }\end{array}$ & Sesuai \\
\hline & $\begin{array}{l}\text { Tambah } \\
\text { Perangkat } \\
\text { Desa } \\
\end{array}$ & $\begin{array}{l}\text { Admin Menekan } \\
\text { Tambah } \\
\text { Perangkat Desa }\end{array}$ & $\begin{array}{l}\text { Menampilkan Form } \\
\text { Input Identitas } \\
\text { Perangkat Desa }\end{array}$ & Sesuai \\
\hline 9 & \multicolumn{4}{|l|}{ Laporan } \\
\hline & Laporan & $\begin{array}{l}\text { Admin Menekan } \\
\text { Laporan }\end{array}$ & $\begin{array}{l}\text { Menampilkan Form } \\
\text { Input Rentang Waktu, } \\
\text { menampilkan data, } \\
\text { dan mencetak laporan }\end{array}$ & Selesai \\
\hline 10 & \multicolumn{4}{|l|}{ Setting } \\
\hline & Desa & $\begin{array}{l}\text { Admin Menekan } \\
\text { Desa }\end{array}$ & $\begin{array}{l}\text { Menampilkan Form } \\
\text { Input Untuk } \\
\text { Mengupdate Data } \\
\text { Desa, dan mengubah } \\
\text { data desa }\end{array}$ & Sesuai \\
\hline & Jabatan & $\begin{array}{l}\text { Admin Menekan } \\
\text { Jabatan }\end{array}$ & $\begin{array}{l}\text { Menampilkan Daftar } \\
\text { Jabatan Perangkat } \\
\text { Desa, dapat } \\
\text { menambah, } \\
\text { mengubah, dan }\end{array}$ & Sesuai \\
\hline
\end{tabular}


Annisa Dwi Rahmawati, Azizah Fatmawati

Sistem Administrasi Desa Mendiro Kecamatan Ngrambe Kabupaten Ngawi Berbasis Web

\begin{tabular}{|l|l|l|l|l|}
\hline No & Pengujian & \multicolumn{1}{|c|}{ Test Case } & \multicolumn{1}{|c|}{ Harapan } & Hasil \\
\hline & & & $\begin{array}{l}\text { menghapus data } \\
\text { jabatan }\end{array}$ & \\
\hline & & Admin Menekan & $\begin{array}{l}\text { Menampilkan Daftar } \\
\text { Devisi Perangkat } \\
\text { Desa, dapat } \\
\text { menambah, } \\
\text { mengubah, dan } \\
\text { menghapus data devisi }\end{array}$ & Sesuai \\
\hline & Devisi & $\begin{array}{l}\text { Menampilkan Daftar } \\
\text { Status Perangkat Desa, } \\
\text { dapat menambah, } \\
\text { mengubah, dan } \\
\text { menghapus data devisi }\end{array}$ & Sesuai \\
\hline
\end{tabular}

\section{2) Pengujian SUS}

Pengujian SUS terdiri dari sepuluh pernyataan sederhana dengan lima poin skala Likert yaitu poin 1 berati Sangat Tidak Setuju (STS) hingga poin 5 berati Sangat Setuju (SS) [23]. Penghitungan hasil SUS sebagai berikut :

1) Perhitungan nilai skor memperhatikan angka ganjil atau genap dari setiap pernyataan.

2) Pernyataan nomor ganjil dihitung dari nilai jawaban dikurangi 1 , pernyataan nomor genap adalah 5 dikurangi dengan pernyataan yang dipilih.

3) Nilai diperoleh dikalikan 2.5 setiap skor lalu totalnya dijumlahkan.

4) Klasifikasi rata-rata nilai skor :

a) Usable,nilai diatas 70

b) Marginal,rata-rata nilai SUS antara 50-70 memiliki arti diperlukan peningkatan sistem yang telah dikembangkan.

c) Unacceptable, jika rata-rata nilai SUS dibawah 50 yang berarti sistem yang dikembangkan tidak dapat diterima.

Tabel 2 merupakan hasil pengelolaan kuisioner menggunakan SUS yang disebar kepada 30 responden.

\begin{tabular}{|c|c|c|c|c|c|c|c|c|c|c|c|c|}
\multicolumn{10}{c|}{ SABEL J HASIL PENGUJIAN SUS } \\
\hline \multirow{2}{*}{ Responden } & \multicolumn{10}{|c|}{ Sumlah } & \multirow{2}{*}{ Nilai } \\
\cline { 2 - 12 } & $\mathbf{1}$ & $\mathbf{2}$ & $\mathbf{3}$ & $\mathbf{4}$ & $\mathbf{5}$ & $\mathbf{6}$ & $\mathbf{7}$ & $\mathbf{8}$ & $\mathbf{9}$ & $\mathbf{1 0}$ & & \\
\hline 1 & 3 & 3 & 4 & 3 & 4 & 3 & 3 & 3 & 4 & 3 & 33 & 82,5 \\
\hline 2 & 4 & 3 & 3 & 2 & 3 & 1 & 3 & 3 & 3 & 3 & 28 & 70 \\
\hline 3 & 4 & 3 & 3 & 3 & 3 & 3 & 3 & 3 & 3 & 3 & 31 & 77,5 \\
\hline 4 & 3 & 1 & 4 & 3 & 3 & 3 & 3 & 3 & 3 & 2 & 28 & 70 \\
\hline 5 & 3 & 1 & 4 & 3 & 3 & 3 & 3 & 1 & 3 & 2 & 26 & 65 \\
\hline 6 & 3 & 1 & 3 & 1 & 3 & 1 & 3 & 2 & 2 & 1 & 20 & 50 \\
\hline 7 & 3 & 3 & 3 & 4 & 2 & 3 & 3 & 3 & 3 & 4 & 31 & 77,5 \\
\hline 8 & 3 & 2 & 3 & 3 & 2 & 1 & 3 & 2 & 3 & 1 & 23 & 57,5 \\
\hline 9 & 3 & 3 & 3 & 3 & 3 & 3 & 3 & 3 & 3 & 2 & 29 & 72,5 \\
\hline 10 & 3 & 3 & 3 & 2 & 2 & 2 & 1 & 3 & 1 & 2 & 22 & 55 \\
\hline 11 & 3 & 1 & 4 & 3 & 3 & 2 & 3 & 3 & 3 & 3 & 28 & 70 \\
\hline 12 & 2 & 1 & 3 & 2 & 2 & 2 & 2 & 2 & 2 & 2 & 20 & 50 \\
\hline 13 & 3 & 1 & 3 & 2 & 3 & 3 & 3 & 3 & 3 & 2 & 26 & 65 \\
\hline 14 & 4 & 0 & 4 & 3 & 3 & 3 & 4 & 4 & 4 & 4 & 33 & 82,5 \\
\hline 15 & 3 & 3 & 4 & 3 & 3 & 3 & 3 & 3 & 3 & 4 & 32 & 80 \\
\hline 16 & 3 & 4 & 3 & 3 & 3 & 3 & 4 & 4 & 3 & 3 & 33 & 82,5 \\
\hline 17 & 2 & 3 & 3 & 3 & 3 & 4 & 3 & 3 & 3 & 4 & 31 & 77,5 \\
\hline 18 & 3 & 3 & 3 & 3 & 1 & 3 & 3 & 3 & 3 & 3 & 28 & 70 \\
\hline 19 & 4 & 2 & 4 & 1 & 4 & 3 & 3 & 2 & 4 & 2 & 29 & 72,5 \\
\hline
\end{tabular}

\begin{tabular}{|c|c|c|c|c|c|c|c|c|c|c|c|c|}
\hline \multirow{2}{*}{ Responden } & \multicolumn{10}{|c|}{ Skor Hasil Hitung } & \multirow{2}{*}{ Jumlah } & \multirow{2}{*}{ Nilai } \\
\hline & 1 & 2 & 3 & 4 & 5 & 6 & 7 & 8 & 9 & 10 & & \\
\hline 20 & 3 & 4 & 4 & 4 & 4 & 3 & 4 & 4 & 4 & 3 & 37 & 92,5 \\
\hline 21 & 3 & 2 & 4 & 2 & 4 & 2 & 3 & 2 & 4 & 2 & 28 & 70 \\
\hline 22 & 4 & 2 & 3 & 3 & 4 & 2 & 3 & 2 & 4 & 4 & 31 & 77,5 \\
\hline 23 & 3 & 4 & 4 & 3 & 4 & 4 & 3 & 3 & 4 & 4 & 36 & 90 \\
\hline 24 & 4 & 3 & 3 & 3 & 3 & 4 & 4 & 4 & 4 & 3 & 35 & 87,5 \\
\hline 25 & 4 & 3 & 4 & 3 & 4 & 4 & 4 & 3 & 4 & 2 & 35 & 87,5 \\
\hline 26 & 4 & 2 & 3 & 2 & 3 & 3 & 3 & 3 & 3 & 2 & 28 & 70 \\
\hline 27 & 3 & 3 & 3 & 2 & 3 & 3 & 2 & 3 & 2 & 2 & 26 & 65 \\
\hline 28 & 3 & 3 & 3 & 3 & 4 & 3 & 2 & 3 & 4 & 2 & 30 & 75 \\
\hline 29 & 3 & 3 & 4 & 3 & 4 & 3 & 4 & 4 & 4 & 2 & 34 & 85 \\
\hline 30 & 3 & 2 & 3 & 2 & 4 & 4 & 4 & 4 & 3 & 2 & 31 & 77,5 \\
\hline & & & & & & & & & & & ta-rata & 73.5 \\
\hline
\end{tabular}

\section{PENUTUP}

\section{A. Kesimpulan}

Berdasarkan pada pengujian Black Box yang telah dilakukan, sistem dapat berjalan sesuai dengan fungsi dan fitur yang telah dirancang sejak awal penelitian. Sistem dapat melakukan pencatatan data penduduk dan melayani pembuatan surat menyurat. Sedangkan berdasarkan kuisioner SUS diperoleh nilai rata-rata 73.5 yang dapat disimpulkan bahwa sistem termasuk dalam kategori Usable.

\section{B. Saran}

Sistem administrasi desa ini dapat dikembangkan lagi pada fitur pembuatan surat internal yaitu surat undangan. Nomor surat undangan dapat dibuat berdasarkan acara / kegiatan yang dilaksanakan, dengan tujuan yang berbeda dalam nomor surat yang sama.

\section{DAFTAR PUSTAKA}

[1] F. Ricky and Minarni, "Sistem linformasi Administrasi Canvasser di PT . Metta Surya Sampit Berbasis Desktop," J. Penelit. Dosen FIKOM, vol. 4, no. 1, pp. 1-5, 2015.

[2] Munawir, Zulfan, Y. Yanti, and Erdiwansyah, "Perancangan Sistem Manajemen Administrasi Gampong Berbasis Aplikasi Desktop," Serambi Eng., vol. II, no. 4, pp. 182-187, 2017.

[3] S. Ria, S. Siregar, and P. Sundari, "Rancangan Sistem Informasi Pengelolaan Data Kependudukan Desa ( Studi Kasus di Kantor Desa Sangiang Kecamatan Sepatan Timur ),” J. Sisfotek Glob., vol. 6, no. 1, pp. 76-82, 2016.

[4] T. Hughes, D. Bence, L. Grisoni, N. O'regan, and and D. Wornham, "Academic-Practitioner Engagement in Business and Management," Int. J. Inform. Organ., vol. 28, no. 2017, pp. 37-43, 2017.

[5] Y. Sibaroni, M. Imrona, E. B. Setiawan, and F. A. Dzuhri, "Aplikasi Pelayanan Administrasi Penduduk Desa Berbasis Web Programing," Semin. Nas. Apl. Teknol. Inf., no. ISSN: 1907 - 5022, pp. 1-6, 2015.

[6] G. Farell, H. K. Saputra, and I. Novid, "Rancang Bangun Sistem Informasi Pengrsipan Surat Menyurat," J. Teknol. Inf. dan Pendidik., vol. 11, no. 2, 2018.

[7] R. M. Syaban and H. Bunyamin, "Pengembangan Sistem Informasi Pengelolaan SUrat Masuk dan Surat Keluar Berbasis Web di Dinas Sosial Tenaga Kerja dan Transmigrasi Kabupaten Garut menggunakan Framework PHP," J. Algoritm. Sekol. Tinggi Teknol. Garut Gambar, vol. 12, no. 1, pp. 1-11, 2015.

[8] M. Badri, "Pembangunan Pedesaan Berbasis Teknologi Informasi dan Komunikasi (Studi pada Gerakan Desa Membangun)," J. Risal., vol. 27 , no. 2, pp. 62-73, 2016

[9] Kartini, "Sistem Informasi Administrasi Pengelolaan Surat di 
Organisasi Berbasis Web," Fak. Komun. dan Inform., no. Tidak diterbitkan, 2017.

[10] A. D. Hamami, "Sistem Informasi Administrasi IMM Komisariat Adam Malik," Fak. Komun. dan Inform., no. Tidak Diterbitkan, 2018 .

[11] K. Setiawan, "Sistem Administrasi Kependudukan Berbasis Web," Fak. Komun. dan Inform., no. Tidak diterbitkan, 2019.

[12] R. Arifiananda and A. Fatmawati, "Sistem Presensi Mahasiswa Berbasis Web dengan Scan QR Code Rindhitya Arfiananda, Azizah Fatmawati," J. Insypro, vol. 4, no. 2, 2019.

[13] Bibit and Sukadi, "Sistem Pengelolaan Surat Masuk Dan Surat Keluar Terkomputerisasi Pada Unit Pelaksana Teknis ( Upt ) Sekolah Menengah Pertama ( SMP ) Negeri 1 Tegalombo," Int. J. Netw. Secur., vol. 4, no. 2, pp. 4-7, 2015.

[14] R. Fitriana, P. Moengin, and M. Riana, "Information system design of inventory control spare parts maintenance (valuation class 5000) ( case study: plant $\mathrm{kw}$ ) Information system design of inventory control spare parts maintenance ( valuation class 5000) ( case study: plant kw )," IOP Conf. Ser. Mater. Sci. Eng., vol. 114, pp. $0-10,2016$.

[15] R. Susanto and A. D. Andriana, "Perbandinagn Model Waterfall dan Prototyping untuk Pengembangan Sistem Informasi," Maj. Ilm. UNIKOM, vol. 14, no. 1, pp. 41-46, 2017.

[16] S. Eroglu, Tolga, and Cakmak, "Enterprise Information Systems within the Context of Information security: A Risk Assessment for a Health Organization in Turkey," Procedia Comput. Sci., vol. 100, pp. 979-986, 2016.
[17] R. S. Madanayake, G. K. A. Dias, and N. D. Kodikara "Transforming Simplified Requirement in to a UML Use Case Diagram Using an Open Source Tool," Int. J. Comput. Sci. Softw. Eng., vol. 6, no. 3, pp. 61-70, 2017.

[18] H. Supriyono, A. M. Noviandri, and Y. E. Purnomo, "Penerapan Sistem Informasi Berbasis Komputer Untuk Pengelolaan Aset Bagi SMP Muhammadiyah 1 Kartasura," 6th Univ. Res. Colloq. 2017, pp. 59-70, 2017.

[19] D. Puput and H. Supriyono, "Rancang Bangun Sistem Presensi Berbasis QR Code Menggunakan Framework Codeigniter ( Studi Kasus Kehadiran Asisten Praktikum )," Insyipro, vol. 4, no. 1, pp. $1-9,2019$.

[20] M. E. Khan and F. Khan, "A Comparative Study of White Box Black Box and Grey Box Testing Techniques," Internasioanl J. Adv. Comput. Sci. Apl., vol. 3, no. 6, pp. 12-15, 2015.

[21] B. Pudjoatmodjo and R. Wijaya, "Tes Kegunaan (Usability Testing) pada Aplikasi Kepegawaian dengan Menggunakan System Usability Scale," Semin. Nas. Teknol. Inf. dan Multimed., vol. 2, no. 9, pp. 37-42, 2016.

[22] K. U. Fitri and A. Fatmawati, "Sistem Informasi Pelanggan pada Bengkel Marno Jaya Motor,” J. Emit., vol. 19, no. 01, pp. 29-35, 2019.

[23] J. Brooke, "SUS - A quick and dirty usability scale," UnitedKingdom, 1986. 